\begin{tabular}{|c|c|c|}
\hline & $\begin{array}{l}\text { European Association for the } \\
\text { Development of Renewable Energies, Environment } \\
\text { and Power Quality (EA4EPQ) }\end{array}$ & $\begin{array}{c}\text { International Conference on Renewable Energies and Power Quality } \\
\text { (ICREPQ' 12) } \\
\text { Santiago de Compostela (Spain), 28th to 30th March, } 2012\end{array}$ \\
\hline
\end{tabular}

\title{
A Simplified Life Cycle Assessment applied to a coupled Solar and Eolic street light
}

\author{
J.-L. Menet ${ }^{1}$ \\ ${ }^{1}$ Ecole Nationale Supérieure d'Ingénieurs en Informatique Automatique Mécanique Energétique et Electronique \\ (ENSIAME) \\ Université Lille Nord de France - Université de Valenciennes et du Hainaut-Cambrésis \\ Campus Le Mont Houy - 59313 Valenciennes CEDEX (France) \\ Phone/Fax number:+0033 0327511426 / +0033 0327511200, e-mail: jean-luc.menet@ univ-valenciennes.fr
}

\begin{abstract}
.
The idea of a street light which would be independent of the power grid and which would be in the same time 'ecological' is to be demonstrated. To answer this question, the environmental impacts of a Solar and Eolic street light called SOLEOL are quantified using a simplified Life Cycle Assessment (i.e. using simplified inputs for the photovoltaic system and the generator). The chosen Functional Unit is: 'the lighting during 25 years with LED lamps with a power of about 2500 lumens'.

The data corresponding to the Life Cycle Inventory are divided into the classical four phases of the Life Cycle Assessment (LCA) methodology.

The environmental impacts are valuated and aggregated; then a comparison is made with a conventional street light. It is shown that the SOLEOL and the conventional street lights are generally at the same level, except for the non-renewable energy consumption where the SOLEOL is better for the environment, and for aquatic toxicity where the SOLEOL street light has a greater impact.

This study shows that a street light said to be environmentally friendly could have in fact a greater impact on the environment, but in our case, and even if no optimization has been made on it, the SOLEOL street light is honorably placed relatively to conventional street lights.
\end{abstract}

\section{Key words}

Street light, Life Cycle Assessment, solar energy, wind energy, renewable energy

\section{Introduction}

Whereas the results are not systematically published, it is known that street lights are responsible of a significant part of the non renewable energy consumption. A rather old paper estimates this energy consumption is about $5 \%$ of electrical energy use [1]. On the other side, street lighting can be correctly designed in order to minimize energy consumption without decreasing the "lighting function" [2].

In order to reduce this conventional energy use, and just after new types of lights and lamps appeared, other street lights have been studied and used with different success. For example, solar powered $[3,4]$ or wind energy street lights [5] have been developed. Hybrid systems have been introduced, using few renewable energy resources for street lighting $[6,7]$. These different products are probably the sign of a new market for street lighting using exclusively renewable energy.

In a recent study, such a concept has been developed at the Engineering School ENSIAME [8]. The idea, partially based on the paper [11], was to design a street light integrating solar and wind energy. Generally, the applied method to design such a product is to 'assemble' existing elements (for example a conventional wind machine connected to a classical generator). But in the considered study, the choice was made to design the whole electromechanical chain in order to increase the global efficiency. However, the resulting street light, which has been called SOLEOL (Solar and EoLic Street Light, figure 1) has not been eco-designed, so that it was not obvious that the SOLEOL street light was environmentally friendly.

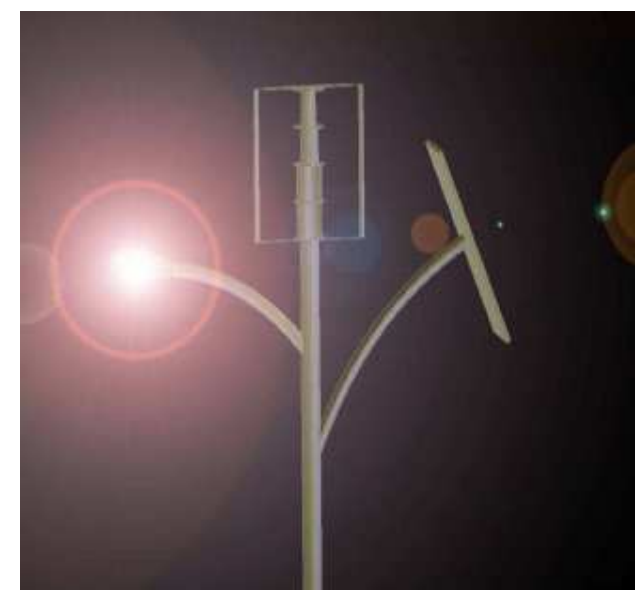

Fig. 1. Design of the SOLEOL street light using a wind turbine and a PV panel

A market research allowed us to identify potential customers, and it appears that these customers could be interested to buy the product at only two conditions: the SOLEOL street light should be sold at around the same price than a conventional street light and it might really be environmentally friendly. 
However, the idea of a street light which would be independent of the power grid and which would be in the same time 'sustainable' is to be demonstrated [12].

In other words, the real question is to know if street lights using renewable energy are really ecological / sustainable, or just examples of 'greenwashing'.

Some studies have been conducted to estimate the environmental impacts of general street lights (see ref [9] for example) or solar powered ones [10]. But at our knowledge, no study has been led to assess the environmental impacts of autonomous wind-solar powered street lights.

The more common and admitted way to rate the 'ecological level' of a product is to follow the Life Cycle Assessment (LCA) methodology. The LCA approach is based on international standards ISO14040 and ISO14044 $[13,14]$ that have been introduced in order to quantify the environmental impact of products and services.

Our purpose is to apply the LCA methodology to the SOLEOL street light [8] represented in figure 1, and to compare the results to the ones obtained on a 'conventional' street light.

In the following, only a simplified method is used. For example, the environmental impacts are underestimated for the photovoltaic panel because the results depend on many parameters [16] or are not totally integrated in the common data bases [17]. The generator, for which environmental data are not available, is just supposed to be a steel complex element, so that the results are also underestimated for it. Besides, few small elements (such as ball bearings) are not considered because it is known that their contribution is very slight compared to the whole system (cutting criteria).

In fact, the aim of the present study is not to give exhaustive results for autonomous street lights but to establish first qualitative conclusions and to show ways of improvement for such a system.

\section{The Life Cycle Assessment methodology}

A Life Cycle Assessment (LCA), also called life cycle analysis, ecobalance or cradle-to-grave-analysis, is the investigation and valuation of the environmental impacts of a given product or service. It is a variant of an inputoutput analysis, focusing on physical rather than monetary flows. LCA is both a multi-criteria and a multi-step study, and is 'goal-dependant'.

A framework for LCA has been standardised by the International Organisation for Standardisation (ISO) in the ISO 14040 series [13, 14]. As shown on figure 2, it consists in the following elements:

- Goal and scope definition: it defines the goal and intended use of the LCA, and scopes the assessment concerning system boundaries, function and flow, required data quality, technology and assessment parameters.

- Life Cycle Inventory, LCI: it is an activity for collecting data on inputs (resources and intermediate products) and outputs (emissions, wastes) for all the processes used to create the product or the system

- Life Cycle Impact Assessment, LCIA: it is the phase of the LCA where inventory data on inputs and outputs are translated into indicators about the product or system and then to potential impacts on the environment.

- Interpretation is the phase where the results of the LCI and LCIA are interpreted according to the goal of the study and where sensitivity and uncertainty analysis are performed to qualify the results and the conclusions.

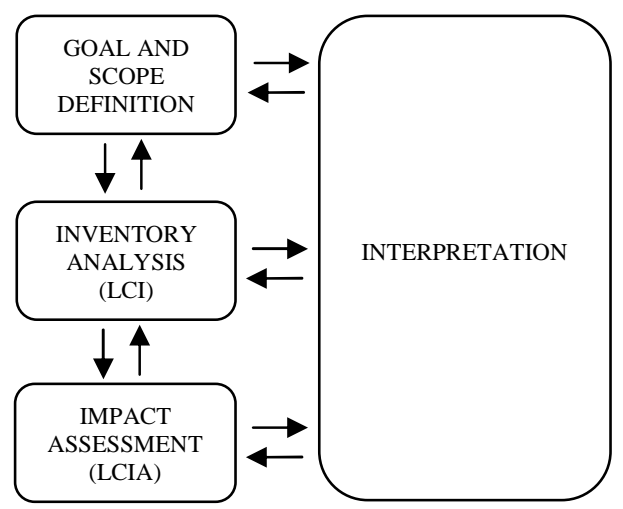

Fig. 2. Phases of a LCA study

\section{LCA methodology applied to the SOLEOL street light}

The SOLEOL street light (fig. 1, [8]) is made of the following elements:

- a concrete block to fix the street light

- a steel mast,

- two coupled vertical axis wind turbines (a Darrieus turbine coupled with a Savonius rotor),

- $\quad$ a $100 \mathrm{Wc}$ photovoltaic (PV) panel,

- 3-cabled girdles

- a converter,

- a generator,

- two lithium-ion batteries,

- $\quad$ a 36 W LED lamp

- $\quad$ two arms for the PV panel and the LED lamp

- few little elements not considered here.

These different elements must be clearly identified in order to obtain accurate data concerning the process. The power diagram of the SOLEOL street light is presented on Figure 3. Let us notice that the SOLEOL street light has been designed to produce 'clean' energy during three nights without any solar energy and wind energy.

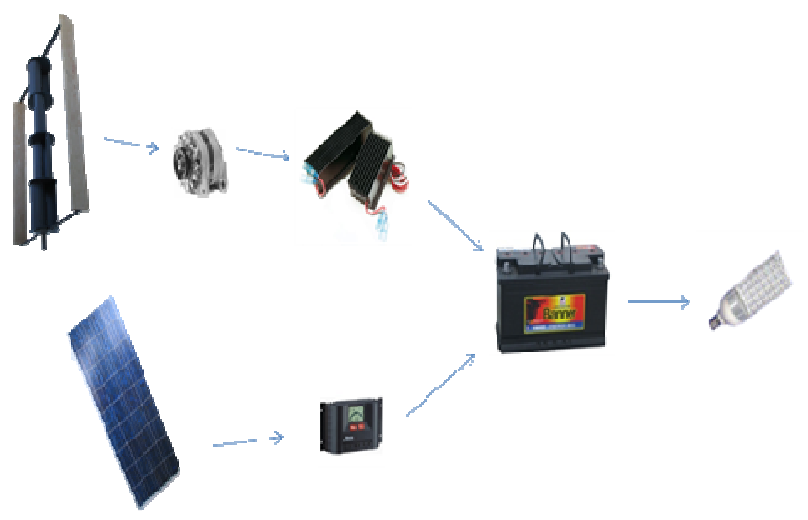

Fig. 3. Power diagram for the SOLEOL street light 
The SOLEOL street light is compared with a 'conventional' street light which is chosen to be the ADI FAD Silver Delta 2001 [15], with LED lamps (Fig. 4). The dimensions of the two street lights are similar.

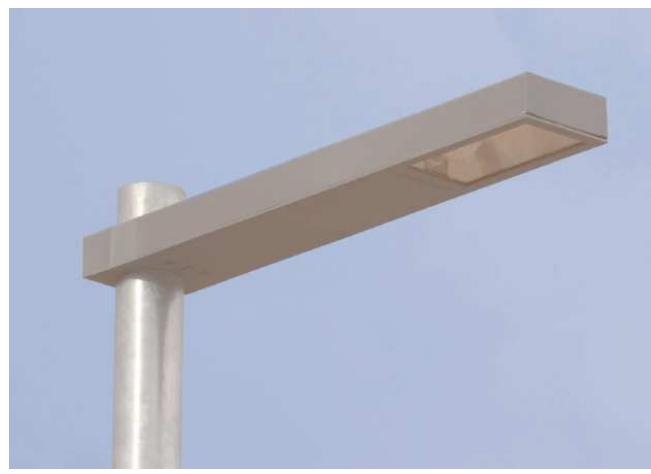

Fig. 4. The chosen conventional street light [15]

In the following, the four steps described in part 2 are used to apply the LCA approach to the SOLEOL street light.

\section{A. Goal and scope of the study}

The final goal of the study is to quantify the environmental impacts of the SOLEOL street light using a Life Cycle Assessment, relatively to the ISO 14040 and 14044 series [13, 14]. The idea is to compare two street lights, on the conditions they enlighten with the same power. The choice of the lighting is made on LED lamps. As a luminous flow of 2500 lumens for street lighting corresponds to a conventional illumination, the chosen resulting Functional Unit is: 'the lighting during 25 years with LED lamps with a luminous flow of about 2500 lumens'.

In the following, only a simplified study is made for the valuation of the environmental impacts. This is mainly due to the fact that the LCA results for photovoltaic systems are not so numerous (see ref [16] for example), so that there are generally not included for the moment in the LCA data bases such as eco-invent [18].

\section{B. LCI: Description of the two street lights}

The data corresponding to the LCI are divided into the classical following four phases of the LCA methodology:

\section{- $\quad$ Phase 1}

The raw material procurement and manufacturing phase takes into account the pollutions created by the use of raw materials to build the product. The different inducted operations in this phase are not detailed here but, for instance, 6 meters of 3-cabled girdle are necessary for SOLEOL vs $58 \mathrm{~m}$ for the conventional street light which is linked to the power grid.

\section{- $\quad$ Phase 2}

The distribution phase takes into account the pollutions produced during the transportation of the product on the place where it is used. We consider that the two street lights are transported within $200 \mathrm{~km}$ using a $32 \mathrm{t}$ truck; The SOLEOL street light weighs $135 \mathrm{~kg}$ whereas the conventional street light weighs $60 \mathrm{~kg}$.

\section{- $\quad$ Phase 3}

In the present case, the consumer use phase only deals with the non-renewable energy consumption of the street light and its maintenance. The SOLEOL street light does not use non-renewable energy. The end of life of the batteries is estimated to 5 years, i.e. about 1000 cycles, so that six batteries must be planned to be changed. The conventional street light uses about $2956 \mathrm{kWh}$ all along its life. The LED lamps, the 'life time' of which is around 5000 hours, will be changed one time. The replacement of the lamps and the batteries is supposed to be made by an employee who drives a conventional vehicle within about $100 \mathrm{~km}$.

\section{- $\quad$ Phase 4}

For the end of life phase (post-consumer use), the different elements are considered as bulky waste.

The considered four phases of the present Life Cycle Inventory (LCI), related to the SOLEOL street light, are represented on figure 5 . The LCI of the conventional street light is not presented here (see ref [8]).

In order to evaluate environmental impacts from the LCI data, the Eco-invent 2.0 data-base is used [18]. The chosen indicators and the corresponding units are referenced in table I.

Table I. - Chosen indicators for the calculation of the environmental impacts

\begin{tabular}{|c|c|c|}
\hline Letter & Indicator & Unit \\
\hline $\mathrm{A}$ & non-renewable energy consumption & $\mathrm{MJ}$ eq. \\
\hline $\mathrm{B}$ & resources depletion & $\mathrm{kg} \mathrm{Sb}$ eq. \\
\hline $\mathrm{C}$ & 100 year Global Warning Potential & $\mathrm{kg} \mathrm{CO}_{2}$ eq. \\
\hline $\mathrm{D}$ & Acidification & $\mathrm{kg} \mathrm{SO}_{2}$ eq. \\
\hline $\mathrm{E}$ & Eutrophication & $\mathrm{kg} \mathrm{PO}^{2-}$ eq. \\
\hline $\mathrm{F}$ & photochemical pollution & $\mathrm{kg} \mathrm{C}_{2} \mathrm{H}_{4}$ eq. \\
\hline $\mathrm{G}$ & aquatic toxicity & $\mathrm{kg} \mathrm{1.4-DB} \mathrm{eq.}$ \\
\hline $\mathrm{H}$ & human ecotoxicity & $\mathrm{kg} 1.4-\mathrm{DB}$ eq. \\
\hline
\end{tabular}

\section{LCIA: Life Cycle Impact Assessment}

The Eco-Invent Basis [18] allows to deduct the potential impacts on the environment for the two studied street lights from the LCI data. The main results of the LCIA calculation for the SOLEOL and the conventional street lights are represented in tables II and III respectively. However, they are not easy to analyze because they are not given in the same Unit (every impact has a corresponding Unit as shown above) and because the different values are not concrete enough. 




Fig. 5. Life Cycle Inventory for the SOLEOL street light

Table II. - LCIA: Environmental impacts for the SOLEOL street light [8]

\begin{tabular}{|c|c|c|c|c|c|c|}
\hline INDICATORS & UNIT & $\begin{array}{c}\text { PHASE 1 } \\
\text { (production) }\end{array}$ & $\begin{array}{c}\text { PHASE 2 } \\
\text { (transportation) }\end{array}$ & $\begin{array}{c}\text { PHASE 3 } \\
\text { (use) }\end{array}$ & END OF LIFE & TOTAL \\
\hline Non-Renewable energy consumption & M eq. & $1,94 \mathrm{E}+04$ & $1,23 \mathrm{E}+02$ & $4,64 \mathrm{E}+03$ & $-2,11 \mathrm{E}+03$ & $2,21 \mathrm{E}+04$ \\
\hline resources depletion & $\mathrm{kg} \mathrm{Sb}$ eq. & $8,90 \mathrm{E}+00$ & $5,38 \mathrm{E}-02$ & $2,31 \mathrm{E}+00$ & $-1,04 \mathrm{E}+00$ & $1,02 \mathrm{E}+01$ \\
\hline $\mathbf{1 0 0}$ year Global Warning Potential & $\mathrm{kg} \mathrm{CO}$ eq. $_{2}$ & $1,24 \mathrm{E}+03$ & $6,96 \mathrm{E}+00$ & $5,15 \mathrm{E}+02$ & $-1,49 \mathrm{E}+02$ & $1,61 \mathrm{E}+03$ \\
\hline Acidification & $\mathrm{kg} \mathrm{SO}$ eq. $_{2}$ & $6,05 \mathrm{E}+00$ & $2,77 \mathrm{E}-02$ & $1,99 \mathrm{E}+00$ & $-6,51 \mathrm{E}-01$ & $7,41 \mathrm{E}+00$ \\
\hline Eutrophication & $\mathrm{kg} \mathrm{PO4} 4^{2-}$ eq. & $7,20 \mathrm{E}-01$ & $5,08 \mathrm{E}-03$ & $1,40 \mathrm{E}-01$ & $-6,89 \mathrm{E}-02$ & $7,96 \mathrm{E}-01$ \\
\hline photochemical pollution & $\mathrm{kg} \mathrm{C} \mathrm{H}_{4}$ eq. & $3,25 \mathrm{E}-01$ & $1,10 \mathrm{E}-03$ & $1,67 \mathrm{E}-01$ & $-5,45 \mathrm{E}-02$ & $4,39 \mathrm{E}-01$ \\
\hline aquatic toxicity & $\mathrm{kg} 1.4-\mathrm{DB}$ eq. & $2,93 \mathrm{E}+02$ & $4,79 \mathrm{E}-01$ & $2,46 \mathrm{E}+02$ & $1,16 \mathrm{E}+02$ & $6,55 \mathrm{E}+02$ \\
\hline human ecotoxicity & $\mathrm{kg} 1.4-\mathrm{DB}$ eq. & $1,34 \mathrm{E}+03$ & $1,61 \mathrm{E}+00$ & $1,46 \mathrm{E}+02$ & $-4,82 \mathrm{E}+02$ & $1,00 \mathrm{E}+03$ \\
\hline
\end{tabular}

Table III. - LCIA: Environmental impacts for the conventional street light [15]

\begin{tabular}{|c|c|c|c|c|c|c|}
\hline INDICATORS & UNIT & $\begin{array}{c}\text { PHASE 1 } \\
\text { (production) }\end{array}$ & $\begin{array}{c}\text { PHASE 2 } \\
\text { (transportation) }\end{array}$ & $\begin{array}{c}\text { PHASE 3 } \\
\text { (use) }\end{array}$ & END OF LIFE & TOTAL \\
\hline Non-Renewable energy consumption & $\mathrm{MJ}$ eq. & $1,07 \mathrm{E}+03$ & $1,15 \mathrm{E}+00$ & $2,71 \mathrm{E}+02$ & $-4,39 \mathrm{E}+02$ & $9,02 \mathrm{E}+02$ \\
\hline resources depletion & $\mathrm{kg} \mathrm{Sb}$ eq. & $4,57 \mathrm{E}-01$ & $5,02 \mathrm{E}-04$ & $7,44 \mathrm{E}-02$ & $-1,91 \mathrm{E}-01$ & $3,40 \mathrm{E}-01$ \\
\hline 100 year Global Warning Potential & $\mathrm{kg} \mathrm{CO}$ eq. $_{2}$ & $6,97 \mathrm{E}+01$ & $6,50 \mathrm{E}-02$ & $1,00 \mathrm{E}+01$ & $-3,15 \mathrm{E}+01$ & $4,82 \mathrm{E}+01$ \\
\hline Acidification & $\mathrm{kg} \mathrm{SO}$ eq. $^{2}$ & $4,73 \mathrm{E}-01$ & $2,58 \mathrm{E}-04$ & $4,83 \mathrm{E}-02$ & $-1,55 \mathrm{E}-01$ & $3,67 \mathrm{E}-01$ \\
\hline Eutrophication & $\mathrm{kg} \mathrm{PO} 4^{2-}$ eq. & $3,14 \mathrm{E}-02$ & $4,74 \mathrm{E}-05$ & $5,06 \mathrm{E}-03$ & $-1,23 \mathrm{E}-02$ & $2,42 \mathrm{E}-02$ \\
\hline photochemical pollution & $\mathrm{kg} \mathrm{C} \mathrm{H}_{4}$ eq. & $1,95 \mathrm{E}-02$ & $1,02 \mathrm{E}-05$ & $2,42 \mathrm{E}-03$ & $-6,33 \mathrm{E}-03$ & $1,56 \mathrm{E}-02$ \\
\hline aquatic toxicity & $\mathrm{kg} \mathrm{1.4-DB}$ eq. & $2,58 \mathrm{E}+01$ & $4,47 \mathrm{E}-03$ & $7,41 \mathrm{E}-01$ & $-1,53 \mathrm{E}+01$ & $1,12 \mathrm{E}+01$ \\
\hline human ecotoxicity & $\mathrm{kg} 1.4-\mathrm{DB}$ eq. & $3,12 \mathrm{E}+02$ & $1,51 \mathrm{E}-02$ & $2,46 \mathrm{E}+00$ & $-1,46 \mathrm{E}+02$ & $1,68 \mathrm{E}+02$ \\
\hline
\end{tabular}


In order to represent these different potential impacts with the same Unit, an identical Y-axis ordinate must be chosen for all the indicators. For each indicator (letter A to $\mathrm{H}$ ), the environmental impact is expressed in Points. The Point represents, considering the studied street light, the potential impact for a given indicator divided by the value of the same impact for a mean European during a day. In other words, the values of the different impacts are simply normalized. The normalization values are given in table IV (basis European Union 2003, [19]).

Table IV. - Normalization values for the indicators

\begin{tabular}{|c|c|c|}
\hline Letter & Indicator & Value \\
\hline $\mathrm{A}$ & N-R energy consumption & $420 \mathrm{MJ}$ eq. \\
\hline $\mathrm{B}$ & resources depletion & $0.0956 \mathrm{~kg} \mathrm{Sb}$ eq. \\
\hline $\mathrm{C}$ & 100 year GWP & $28.1 \mathrm{~kg} \mathrm{CO}_{2}$ eq. \\
\hline $\mathrm{D}$ & Acidification & $0.123 \mathrm{~kg} \mathrm{SO}_{2}$ eq. \\
\hline $\mathrm{E}$ & Eutrophication & $0.105 \mathrm{~kg} \mathrm{PO}^{2-}$ eq. \\
\hline $\mathrm{F}$ & photochemical pollution & $0.015 \mathrm{~kg} \mathrm{C}_{2} \mathrm{H}_{4}$ eq. \\
\hline $\mathrm{G}$ & aquatic toxicity & $2.8 \mathrm{~kg} 1.4-\mathrm{DB}$ eq. \\
\hline $\mathrm{H}$ & human ecotoxicity & $56.3 \mathrm{~kg} 1.4-\mathrm{DB}$ eq. \\
\hline
\end{tabular}

The results of the Life Cycle Impact Assessment are presented on figure 6 . It is shown that it is preferentially the manufacturing phase which is the source of the greater impact on the environment, whatever the indicator. The aquatic toxicity is clearly the impact which is the greater disadvantage for the SOLEOL street light according to the environment.

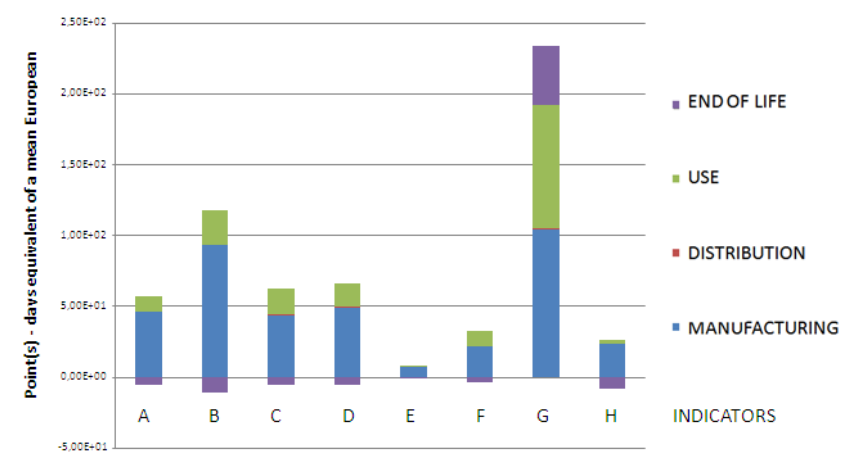

Fig. 6. Environmental impacts for the SOLEOL street light

At this step, it appears that the quantitative results are not significant because no reference exists. It is the reason why, according to the LCA methodology which is 'goal dependant', the SOLEOL is to be compared with a more conventional street light [15] represented in figure 2. Let us notice that the street light [15] is already said to be a 'clean' light, particularly because of the use of LED lamps. As it has been written previously, the data of the Life Cycle Inventory for the conventional street light is not presented here, but the resulting potential impacts are estimated.

Figure 7 presents the compared impacts for the two street lights, for each phase of life. As it could be expected, for the conventional street light, the consumer use phase is responsible of the supplementary consumption energy and resources, relatively to the SOLEOL street light. This is due to the non-renewable energy which is used by the conventional street light. For the SOLEOL street light, the consumer use phase has a great impact considering aquatic toxicity, which is due to the use of the batteries. The negative part for the conventional street light can be explained because the copper cables can be easily recycled.

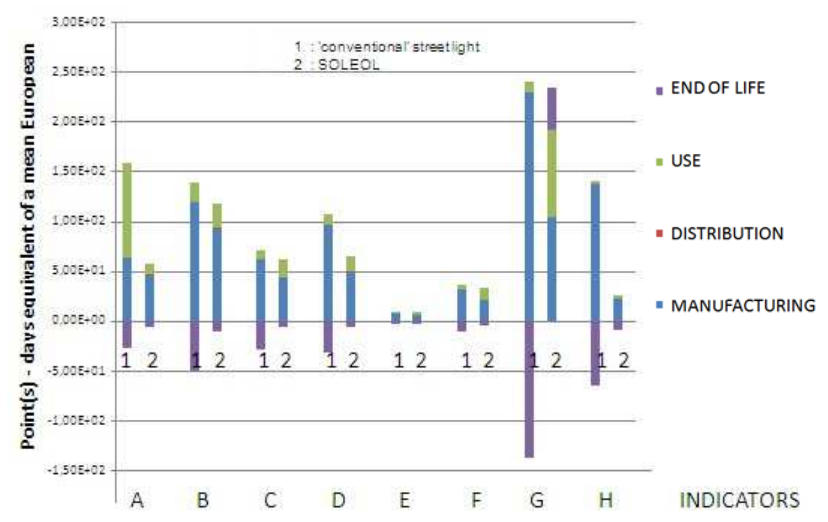

Fig. 7. Environmental impacts for the two street lights

\section{Interpretation}

If the results are aggregated for all phases of life, it is easier to compare the two street lights. Figure 8 presents a comparison of the global impacts for the two street lights, aggregated for the whole life cycle of the products.



Fig. 8. Aggregated results for the two street lights

As the same Unit is used for the representation of the potential impacts, it is possible to add the obtained value for each indicator to give a 'global rating'. This 'global note' can only give an indication about the total impact ; in fact, if this 'global note' was used alone, it could mask some important information coming from the LCA results (for example a very high impact for one indicator). The results for this 'global note' give 565 points for the SOLEOL street light and 552 points for the conventional one. The accuracy of the data and of the methodology is not sufficient enough to make a difference between these two results, i.e. the two studied street lights can be said to have globally the same potential impact on the environment. 
More particularly, The SOLEOL and the conventional street lights are generally at the same level, except for the non-renewable energy consumption where the SOLEOL street light is better for the environment. On the other side, concerning aquatic toxicity, the SOLEOL street light has a much greater impact; this is mainly is due to the use of batteries, as it can be shown using a comparison between the SOLEOL street light LCA with and without batteries (figure 9). This question could be quickly solved by the choice of alternative batteries, more environment-friendly and with a higher 'life time', or by a re-conception of SOLEOL which was made to be used during three days without wind and solar energy.

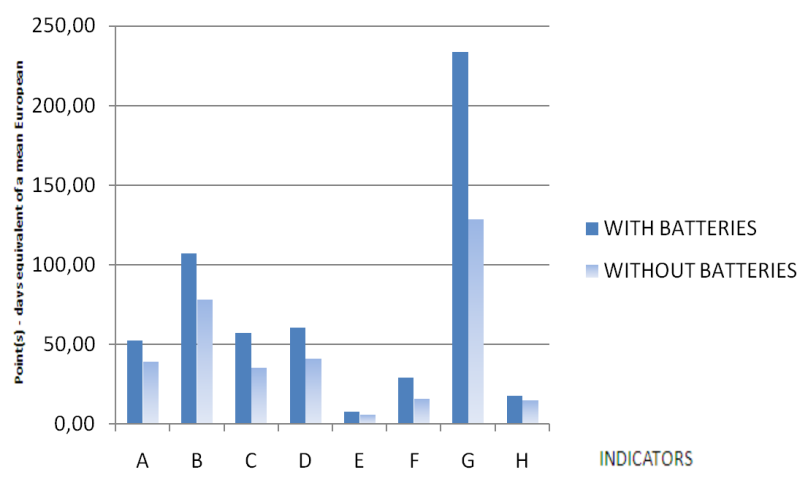

Fig. 9. Influence of the batteries for the SOLEOL street light (aggregated results)

\section{Conclusion}

The LCA methodology is described and applied to the study of a new type of street light using exclusively wind and solar energy.

The indicators are chosen and estimated for the classical four phases of life. The main result is that it is the manufacturing phase which has the main impact on the environment.

The results are compared to the ones estimated for a conventional street light. Concerning the environmental impacts, the SOLEOL and the chosen conventional street light are globally of the same order of magnitude, except for the non-renewable energy consumption where the SOLEOL is better for the environment, and for aquatic toxicity where the SOLEOL street light has a much greater impact.

In a general way, the first approach used in this study does not 'disqualify' the SOLEOL concept, which keeps serious advantages, as far as it has been compared with a 'conventional' street light using LED lamps and not sodium lights for example. This study shows that a street light using exclusively 'green energy' could in fact have a greater impact on the environment than conventional street lighting. However, although no optimization has been made, the SOLEOL street light is globally at the same level than the conventional street lights concerning the environmental indicators used in the present study. It is clear that optimizations are necessary and that they will lead to a better positioning of the SOLEOL prototype.

\section{Acknowledgement}

This study has been partly made using the free 'Bilan Produit' ® software [19] jointly developed by the French Agency for the Environment and the Energy (ADEME) and the Cergy-Pontoise University.

The author thanks the students Bastien Breton, Stéphane Brisoux and Mathieu Legrand, who have contributed to design the SOLEOL concept.

\section{References}

[1] B. Multon, L'énergie électrique : analyse des ressources et de la production, Journées électrotechniques du Club EEA Paris 28-29 janvier 1999.

[2] M. Kostic, L. Djokic, Recommendations for energy efficient and visually acceptable street lighting, Energy 34 (2009), pp1565-1572.

[3] M. Fathi, A. Chikouche, M. Abderrazak, Design and realization of LED Driver for solar street lighting applications, Energy Procedia 6 (2011), pp 160-165.

[4] Y. X. Liu, Solar Led Lamp, Patent Application Publication, US 1010/0079984ª 1, Apr. 1, 2010.

[5] C.C. Hu, C.-M. Lai, Street lamp system, United States Design Patent US 7780320B2, Aug. 24, 2010.

[6] J. Lagorse, D. Paire, A. Miraoui, Sizing optimization of a stand-alone street lighting system powered by a hybrid system using fuel cell, PV and battery, Renewable Energy 34 (2009), pp 683-691.

[7] P. D. Daidone, L.E. Ascani, Wind and solar-powered light post, United States Design Patent USD626686S, Nov. 2, 2010.

[8] B. Bastien, D. Jaussaud, F. Juras, M. Legrand, J.-L. Menet, SOLEOL - Conception d'un lampadaire autonome, Project report PLP-2010-INT3, Université de Valenciennes et du Hainaut-Cambrésis, 2010.

[9] D. Hartley, C. Jurgens, E. Zatcoff, Life Cycle Assessment of Streetlight Technologies, Mascaro Center for Sustainable Innovation, University of Pittsburgh, Pittsburgh, PA, July 30, 2009.

[10] J. G. M. Kortman, M. G. H. Van Kampen, L. A. Verhoef, A Life Cycle Assessment of the Environmental Impact of Photovoltaic Streetlight Systems, Netherlands Agency for Energy and the Environment, University of Amsterdam, P.O. Box 18180, 1001 ZB Amsterdam, The Netherlands

[11] J.-L. Menet, A double-step Savonius rotor for local production of electricity: a design study, Renewable Energy, vol 29, pp 1843-1862, 2004

[12] J.-L. Menet, B., S. Brisoux, M. Legrand, Simplified comparative LCA of a conventional and a 'sustainable' street light, 1st LCA Conference, Lille, Nov. 3-4 2011.

[13] ISO 14040, Environmental Management - Life Cycle Assessment, Principles and framework (2006)

[14] ISO 14044, Environmental Management - Life Cycle Assessment, Requirements and guidelines (2006)

[15] http://www.santacole.com/recursos/productos/downloads/ pdf_espec_tecnicas/RAMA_ht_en.pdf

[16] D. Beloin-Saint-Pierre, I. Blanc, J. Payet, P. Jacquin, N. Adra, D. Mayer, Environmental impact of PV systems: effects of energy sources used in production of solar panels, 24th European Photovoltaic Solar Energy Conference, Hamburg : Germany (2009)

[17] N. Jungbluth, M. Tuchschmid, R.Dones, Photovoltaics: ecoinvent report No. 6-XII. Swiss Centre for Life Cycle Inventories, Dübendorf, CH. (2007)

[18] http://www.ecoinvent.ch/

[19] http://www.ademe.fr/bilanproduit 